\title{
Pendampingan bagi Para Tenaga Kerja sebagai Peserta BPJS Ketenagakerjaan di Kediri
}

\author{
Hilda Yunita Sabrie, Rizky Amalia, Erni Agustin dan Ananda Amalia Tasya \\ hilda_sabrie@yahoo.co.id \\ Universitas Airlangga
}

\begin{abstract}
Every Indonesian citizen has the same rights in terms of getting health, education and decent work. This is a mandate from the Constitution of the Republic of Indonesia that must be realized by the Government. For that, slowly but surely, the Government has socialized several pro-people programs, one of which is by presenting the Social Security Organizing Agency (BPJS) program. BPJS has 2 large programs namely in terms of health and employment. For this assistance more focused on BPJS Employment. This is because in some areas there are still many misunderstandings or even do not care about the BPJS Employment program, especially for employers or the employers. If this continues, the rights of the workers will be ignored and will certainly harm the workers themselves. So with this assistance, employers are expected to be more concerned with the welfare and safety of workers. Also on this mentoring, a tutorial will be given on how to register workers with the BPJS Employment. In addition, an explanation will also be given regarding the rights and obligations as a member of the BPJS Employment, and not forgetting how to submit a claim if there is an employee who has an accident while carrying out his work. This assistance was carried out in Kediri, with the main target being traditional workers.
\end{abstract}

Keywords:Employment BPJS; Workers; Employers.

\begin{abstract}
Abstrak
Setiap warga negara Indonesia memiliki hak yang sama dalam hal mendapatkan kesehatan, pedidikan dan pekerjaan yang layak. Hal tersebut merupakan amanah dari Undang-Undang Dasar Republik Indonesia yang harus diwujudkan oleh Pemerintah. Untuk itu perlahan namun pasti, Pemerintah telah mensosialisasikan beberapa program yang pro rakyat, salah satunya adalah dengan menghadirkan program Badan Penyelenggara Jaminan Sosial (BPJS). BPJS memiliki 2 program besar yaitu dalam hal kesehatan dan ketenagakerjaan. Untuk pendampingan ini lebih di fokuskan kepada BPJS Ketenagakerjaan. Hal ini karena di beberapa daerah masih banyak dijumpai ketidak pahaman atau bahkan tidak peduli terhadap program BPJS Ketenagakerjaan ini, terutama bagi pengusaha atau si pemberi kerja. Jika hal ini terus terjadi maka hak-hak para pekerja akan terabaikan dan tentu akan merugikan para pekerja itu sendiri. Sehingga dengan adanya pendampingan ini, diharapkan para pengusaha nantinya akan lebih peduli terhadap kesejahteraan dan keselamatan pekerja. Pada pendampingan ini pula, nantinya akan di berikan tutorial terkait bagaimana cara mendaftarkan para pekerja ke BPJS Ketenagakerjaan. Selain itu akan di beri penjelasan pula terkait hak dan kewajiban sebagai anggota dari BPJS Ketenagakerjaan, serta tidak lupa cara mengajukan klaim apabila ada pekerja yang mengalami kecelakaan saat menjalankan pekerjaannya. Pendampingan ini dilakukan di Kediri, dengan sasaran utamanya adalah pekerja tradisonal.
\end{abstract}

Kata Kunci: BPJS Ketenagakerjaan; Pekerja; Pengusaha.

\section{Pendahuluan}

Usaha Mikro, Kecil dan Menengah (UMKM) di kota Kediri terus berkembang. Hal ini terlihat dari pemasarannya yang sudah skala nasional dan 
interasional selain itu juga banyak bermunculan wirausahawan-wirausahawan baru di kota Kediri. Pada tahun 2017, pertumbuhan ekonomi kota Kediri Non Industri Tembakau mencapai 7,02\%. Selain itu, menurut data BPS Tahun 2018 menunjukkan bahwa angka pengangguran terbuka di kota Kediri turun di bawah angka pengangguran terbuka Provinsi Jawa Timur yaitu sebesar 3,63\% dari Provinsi Jawa Timur sebesar 3,99\%. Pada tahun 2018, kota Kediri juga berhasil menekan angka kemiskinan sebesar 7,68\%. Penurunan kemiskinan di kota Kediri ini, berada di bawah capaian nasional sebesar 9,82\% dan capaian Jawa Timur sebesar 10,98\%. Ini menunjukkan bahwa UMKM di kota Kediri berkembang dan memiliki peran strategis dalam menurunkan angka kemiskinan dan pengangguran dengan jumlahnya saat ini mencapai 38.806 usaha. ${ }^{1}$

Banyaknya jumlah pengusaha di Kediri, membuat pemerintah daerah setempat terbantu karena angka pengangguran di kota tersebut menjadi berkurang. Keuntungan lainnya adalah meningkatnya perkembangan usaha mikro dan kecil di daerah tersebut. Selain itu untuk mempertahankan eksistensi dari usahanya tersebut, telah banyak inovasi yang dilakukan oleh para pengusaha yang dibantu oleh para pekerja dengan membuat makanan lain yang berbahan dasar salah satunya adalah gula. Sektor ekonomi yang sangat berkembang pesat di kota Kediri membuat masyarakat Kediri menjadi lebih sejahtera, terutama bagi para pengusaha dan pekerja di bidang usaha perkebunan.

Selain memperhatikan sektor ekonomi perlu juga mentelaah sektor lain yaitu perlindungan hukum bagi para pekerja, dalam hal ini di bidang usaha perkebunan (contoh: gula). Bagaimana hak dan kewajiban pengusaha kepada para pekerjanya. Hal ini yang perlu di bahas lebih lanjut dan lebih di fokuskan kepada apakah pekerja tersebut telah terdaftar sebagai pesertaan asuransi BPJS Ketenagakerjaan. Hal ini perlu karena sebagian besar pekerja adalah masyarakat tradisional yang kesehariannya hanya menjalankan pekerjaan sehari-hari, dengan kemampuan atau skill yang terbatas tanpa sempat memikirkan hak-hak lainnya sebagai pekerja,

\footnotetext{
${ }^{1}$ Achmad Saichu, 'UMKM Berkembang Pesat, Wali Kota Kediri Raih Penghargaan Sebagai Bapak Enterpreneur' (koranmemo.com, 2019).
} 
seperti menjadi peserta BPJS Ketenagakerjaan. Hasil penelitian lainnya adalah sebagian dari mereka belum terdaftar bahkan belum memahami secara detail tentang keberadaan ataupun manfaat dari BPJS Ketenagakerjaan.

BPJS Ketenagakerjaan merupakan program publik yang memberikan perlindungan bagi tenaga kerja untuk mengatasi risiko sosial ekonomi tertentu dan penyelenggaraannya menggunakan mekanisme asuransi sosial. Sebagai Lembaga Negara yang bergerak dalam bidang asuransi sosial BPJS Ketenagakerjaan yang dahulu bernama PT Jamsostek (Persero) merupakan pelaksana undang-undang jaminan sosial tenaga kerja. BPJS Ketenagakerjaan sebelumnya bernama Jamsostek (jaminan sosial tenaga kerja), yang dikelola oleh PT. Jamsostek (Persero), namun sesuai UU No. 24 Tahun 2011 tentang BPJS, PT. Jamsostek berubah menjadi BPJS Ketenagakerjaan sejak tanggal 1 Januari 2014. BPJS Kesehatan, dimana dahulu bernama Askes bersama BPJS Ketenagakerjaan merupakan program pemerintah dalam kesatuan Jaminan Kesehatan Nasional (JKN) yang diresmikan pada tanggal 31 Desember 2013. Untuk BPJS Kesehatan mulai beroperasi sejak tanggal 1 Januari 2014, sedangkan BPJS Ketenagakerjaan mulai beroperasi sejak 1 Juli 2015. Sebagai program publik, BPJS Ketenagakerjaan memberikan hak dan membebani kewajiban secara pasti. BPJS Ketenagakerjaan mengatur Jenis Program Jaminan Kecelakaan Kerja (JKK), Jaminan Hari Tua (JHT), Jaminan Kematian (JKM) dan Jaminan Pemeliharaan Kesehatan (JPK), sedangkan kewajiban peserta adalah tertib administrasi dan membayar iuran.

Sifat kepesertaan dari BPJS Ketenagakerjaan adalah wajib. Artinya setiap warga negara yang telah memenuhi persyaratan dalam undang-undang maka wajib mengikuti program tersebut. Sehingga di harapkan sasaran dari program ini dapat tercapai dan terwujud, dapat dinikmati manfaatnya oleh sebagian besar rakyat Indonesia. Untuk itulah pendampingan ini dilakukan, untuk mendukung program publik dari pemerintah. Sehingga paling tidak para pengusaha tahu berkenan untuk mendaftarkan pekerja tau tenaga kerjanya ke BPJS Ketenagakerjaan, pekerja atau tenaga kerja yang ada di Kediri (bidang produksi tahu) dapat menjadi peserta BPJS Ketenagakerjaan sekaligus mengetahui tat cara pembayaran premi sampai dengan proses pengajuan klaimnya. 
BPJS Ketenagakerjaan menyelenggarakan 4 Program yakni Program Jaminan Kecelakaan Kerja (JKK), Jaminan Hari Tua (JHT), Jaminan Pensiun (JP), dan Jaminan Kematian ( JK). Menurut UU BPJS, pemberi kerja atau pengusaha wajib mendaftarkan seluruh pekerjanya menjadi peserta BPJS Ketenagakerjaan dan BPJS Kesehatan secara bertahap menurut ketentuan perundang-undangan. Pengusaha dalam hal ini selain mendaftarkan juga menarik iuran dari pekerja dan membayarkan berdasarkan pembagian kewajiban antara pengusaha dan Pekerja. Kewajiban masing-masing pihak adalah sebagai berikut:

1. Pemberi Kerja:

a. JKK : $0.24 \%$ - $1.74 \%$ (sesuai dengan rate kecelakaan kerja berdasarkan lampiranPeraturanPemerintahNomor44Tahun2015 tentang Penyelenggaraan Program Jaminan Kecelakaan Kerja dan Jaminan Kematian)

b. JK : $0.3 \%$ c. JHT : $3.7 \%$ d. JP : $2 \%$

\section{Pekerja:}

a. JHT : $2 \%$

b. JP : $1 \%$

Apabila terjadi risiko sosial terhadap pekerja baik itu kecelakaan kerja, kematian, hari tua, maupun pensiun maka BPJS Ketenagakerjaan akan memberikan manfaat kepada peserta dalam bentuk pelayanan maupun uang tunai. Manfaat pelayanan yang dimaksud adalah apabila terjadi kecelakaan kerja, maka pekerja dapat langsung dibawa ke fasilitas kesehatan yang bekerja sama dengan BPJS Ketenagakerjaan baik klinik maupun rumah sakit (trauma center) tanpa mengeluarkan biaya dengan menunjukkan kartu BPJS Ketenagakerjaan apabila pemberi kerja (perusahaan) tertib membayarkan iuran kepada BPJS Ketenagakerjaan. Apabila tidak terdapat fasilitas kesehatan yang bekerja sama, maka pekerja tetap mendapatkan manfaat JKK tersebut dengan sistem reimbursemen. Sedangkan manfaat uang tunai akan didapatkan oleh pekerja maupun ahli warisnya apabila terjadi risiko meninggal dan hari tua/pensiun. Perbedaan antara Jaminan Hari Tua dan Jaminan Pensiun terletak pada manfaat yang akan diterima oleh pekerja dan /atau ahli warisnya. Manfaat Jaminan Hari Tua diterima sekaligus ketika pekerja memenuhi ketentuan 
pengambilan yakni usia pensiun (56), meninggal dunia, cacat total tetap, atau berhenti bekerja dan tidak bekerja lagi, sementara untuk manfaat Jaminan Penisun akan diterima secara berkala setiap bulan kepada Pekerja dan/atau ahli waarisnya apabila pekerja memasuki usia pensiun (56) dengan minimal iuran 15 Tahun, meninggal dunia (dengan iuran minimal dibayar 12 bulan), atau cacat total tetap (iuran minimal 1 bulan). Apabila ketiga syarat tersebut belum terpenuhi, maka pekerja dan/atau ahli warisnya akan mendapatkan manfaat berupa akumulasi iuran ditambah dengan pengembangannya.

\section{Metode}

Adapun metode pelaksanaan dalam pengabdian masyarakat ini secara umum adalah memberikan pendampingan bagi tenaga kerja yang belum terdaftar sebagai peserta BPJS Ketenagakerjaan. Untuk itu perlu dicari suatu perusahaan tradisional atau pekerja tradisional yang ada di Kediri. Dengan cara pertama dilakukan survey dan perijinan terkait dengan topik yang diangkat. Kemudian melakukan pendampingan dengan memberikan sosialisasi tentang manfaat asuransi terutama BPJS Ketenagakerjaan bagi pekerja dan pengusaha. Selanjutnya adalah memberikan panduan terkait cara pendaftaran anggota BPJS Ketenagakerjaan, pembayaran premi, hak dan kewajiban sebagai anggota dan panduan pengajuan klaim, baik kepada Pemberi kerja (pengusaha) maupun kepada pekerja. Apabila terdapat kendala setelah pelaksanaan pengambdian masyarakat ini makaakan diadakan asistensi dalam pengurusan kepesertaan BPJS Ketenagakerjaan termasuk dalam pengajuan klaim untuk seluruh tenaga kerja setempat.

\section{Hasil dan Pembahasan}

Sebagai bagian dari kebijakan jaminan sosial tenaga kerja dari pemerintah. Setiap tenaga kerja wajib mendaftarkan diri lewat program BPJS Ketenagakerjaan. Berikut ini adalah berbagai jenis program BPJS Ketenagakerjaan yang bisa dinikmati oleh para tenaga kerja. 
- Program Jaminan Kecelakaan Kerja (JKK): Program yang memberikan perlindungan atas berbagai risiko kecelakaan yang terjadi dalam hubungan kerja. Termasuk kecelakaan yang terjadi dalam perjalanan dari rumah ke tempat kerja atau sebaliknya, serta penyakit yang disebabkan oleh lingkungan kerja.

- Program Jaminan Kematian (JKM): Program yang memberikan manfaat berupa uang tunai yang akan diberikan kepada ahli waris ketika peserta meninggal dunia saat kepesertaan masih aktif dan bukan disebabkan oleh kecelakaan kerja.

- Program Jaminan Hari Tua (JHT): Program yang memberikan manfaat berupa uang tunai yang besarannya merupakan akumulasi iuran ditambah dengan hasil pengembangannya untuk jaminan hidup di hari tua.

- Program Jaminan Penisun (JP): Program jaminan sosial yang memiliki tujuan untuk mempertahankan derajat kehidupan dengan memberikan penghasilan ketika peserta memasuki usia pensiun, mengalami cacat total tetap, atau meninggal dunia. Manfaat pensiun ini diberikan dalam bentuk uang yang dibayarkan setiap bulan.

Tujuan dari program-program yang ditawarkan oleh BPJS Ketenagakerjaan adalah untuk mencapai kesejahteraan ekonomi dan sosial. Para pekerja diharapkan dapat meminimalisir risiko peristiwa tidak pasti maupun pada saat usia tua atau memasuki usia pensiun. Setiap warga negara yang tinggal di Indonesia dan bekerja memiliki jenis keanggotaan program BPJS Ketenagakerjaan yang berbeda-beda. Program jaminan yang diberikan pun juga berbeda tergantung jenis keanggotaan yang dimiliki oleh peserta. Berikut ini adalah jenis keanggotaan yang dikelompokkan menurut pekerjaan:

- Penerima Upah (PU)

Pekerja Penerima Upah (PU) adalah setiap orang yang bekerja dengan menerima gaji, upah, atau imbalan lain dari pemberi kerja.

\section{- Bukan Penerima Upah (BPU)}

Pekerja Bukan Penerima Upah (BPU) adalah setiap pekerja yang melakukan 
kegiatan atau usaha ekonomi secara mandiri untuk memperoleh penghasilan dari kegiatan atau usahanya tersebut.

\section{- Jasa Konstruksi}

Jasa Konstruksi adalah orang yang bekerja pada layanan jasa konsultasi perencanaan pekerjaan konstruksi, layanan jasa pelaksanaan pekerjaan konstruksi atau layanan konsultasi pengawasan pekerjaan konstruksi.

\section{- Pekerja Migran}

Pekerja Migran Indonesia adalah setiap warga negara Indonesia yang akan, sedang, atau telah melakukan pekerjaan dengan menerima upah di luar wilayah Republik Indonesia (luar negeri).

BPJS Ketenagakerjaan tetap memiliki tanggung jawab terhadap para pekerja yang terdahulu merupakan peserta Jamsostek. Hal ini didasarkan pada Pasal 62 UU BPJS dimana kepesertaan pada Jamsostek otomatis menjadi peserta BPJS Ketenagakerjaan berkaitan dengan transformasi tersebut. Tanggung jawab tersebut dimaksudkan untuk mewujudkan terselenggaranya pemberian jaminan pemenuhan kebutuhan dasar hidup yang layak bagi setiap peserta dan/atau anggota keluarganya. Dengan demikian, peserta Jamsostek berubah menjadi peserta BPJS Ketenagakerjaan dan diberikan hak yang sama sebagaimana peserta BPJS Ketenagakerjaan lainnya. Berikut beberapa syarat dokumen yang perlu disiapkan oleh pemberi kerja dan pekerja penerima upah ketika akan mendaftarkan diri dalam program BPJS Ketenagakerjaan:

a. Asli dan salinan SIUP atau Surat Izin Usaha Perdagangan.

b. Asli dan salinan NPWP Perusahaan.

c. Asli dan salinan Akta Perdagangan Perusahaan.

d. Salinan KTP atau Kartu Tanda Penduduk masing-masing karyawan.

e. Salinan KK atau Kartu Keluarga masong-masing karyawan.

f. Pas foto warna Karyawan, ukuran 2 x 3 sebanyak 1 lembar.

Sedangkan dalam hal pendaftaran BPJS Ketenagakerjaan bagi pekerja bukan penerima upah, dibutuhkan suatu organisasi yang terdiri dari minimal 10 orang yang kemudian didaftarkan BPJS Ketenagakerjaan. Berikut ini beberapa syarat dokumen yang dibutuhkan untuk mendaftarkan BPJS Ketenagakerjaan bagi para pekerja mandiri: 
a. Surat izin usaha dari kelurahan setempat.

b. Salinan KTP masing-masing pekerja.

c. Salinan KK / Kartu Keluarga masing-masing pekerja.

d. Pas foto warna masing-masing pekerja ukuran $2 \times 3$ sebanyak 1 lembar.

Selain untuk memberi perlindungan dan perhatian terhadap keselamatan kerja bagi para pekerja, BPJS Ketenagakerjaan secara tidak langsung juga dimaksudkan untuk melindungi pemberi kerja atau perusahaan agar tetap berdiri dan berkembang dengan terpeliharanya kesehatan, kesejahteraan, dedikasi dan kedisiplinan dari para pekerjanya.2 Hal tersebut menjadi faktor yang penting untuk menjaga performa kerja para pekerja agar dapat memberikan hasil yang maksimal dalam bekerja.

Dalam hal peserta BPJS Ketenagakerjaan yang telah melaksanakan kewajibannya tidak mendapatkan hak sebagaimana telah diatur dalam UU BPJS, peserta dapat melakukan upaya hukum untuk menuntut hak-haknya. Beberapa upaya hukum penyelesaian sengketa yang dapat ditempuh antara lain melalui:

\section{Pengaduan}

Berdasarkan Pasal 3 Peraturan BPJS No. 6 Tahun 2015 tentang Unit Pengendali Mutu Pelayanan dan Penanganan Pengaduan Peserta, peserta BPJS dapat melakukan pengaduan atas ketidakpuasan pelayanan yang diberikan disertai bukti yang valid. Pengaduan tersebut dapat dilakukan dengan cara bertatap muka dengan petugas BPJS yang menangani pengaduan peserta di seluruh Kantor BPJS Ketenagakerjaan, menyampaikan pengaduan pada saat kunjungan resmi petugas BPJS Ketenagakerjaan, atau dapat melalui pusat layanan informasi BPJS Ketenagakerjaan. Pengaduan dapat dilakukan secara tidak langsung melalui kotak saran, PO Box, e-mail, SMS, website, atau media sosial.

\section{Mediasi}

Berdasarkan Pasal 5 Peraturan BPJS No. 6 Tahun 2015, apabila peserta merasa belum puas dan menimbulkan sengketa pada saat penyelesaian pengaduan, maka peserta dapat mengajukan penyelesaian sengketa melalui mediasi. Mediasi adalah

\footnotetext{
2 Hani Regina Sari, 'Perlindungan Hukum Tenaga Kerja Oleh Badan Penyelenggara Jaminan Sosial Ketenagakerjaan Berdasarkan Undang-Undang No. 24 Tahun 2011' [2018] Jurnal Ilmiah Fakultas Hukum Universitas Lampung Bandar Lampung.
} 
proses negosiasi pemecahan masalah dimana piha luar yang tidak memihak (imparsial) bersifat netral dan bekerjasama dengan pihak yang bersengketa untuk mencari kesepakatan bersama. Mediasi dilakukan oleh seorang mediator yang tidak berwenang untuk memutus sengketa, tetapi hanya membantu para pihak untuk menyelesaikan persoalan yang bersifat win-win solution. Mediasi tersebut dilakukan paling lama 30 (tiga puluh) hari, dan dilaksanakan sesuai dengan ketentuan dalam peraturan perundang-undangan.

\section{Badan Penyelesaian Sengketa Konsumen (BPSK)}

BPSK adalah badan yang bertugas menangani dan menyelesaikan sengkea antara pelaku usaha dan konsumen yang khusus dibentuk dan diatur dalam UndangUndang Perlindungan Konsumen. BPSK berwenang untuk melaksanakan penanganan dan penyelesaian konsumen melalui konsiliasi, mediasi dan arbitrase. Putusan BPSK bersifat final dan mengikat. Salah satu program BPJS Ketenagakerjaan adalah Jaminan Kematian yang merupakan program asuransi yang melibatan pelayanan rumah sakit maupun unit kesehatan lainnya apabila peserta BPJS Ketenagakerjaan mengalami kecelakaan kerja atau sakit. Sehingga, peserta BPJS Ketenagakerjaan sebagai konsumen dari rumah sakit atau unit kesehatan tersebut dapat mengajukan penyelesaian sengketa melalui BPSK.

\section{Pengadilan}

Apabila peserta BPJS tidak dapat menyelesaikan sengketa melalui mediasi dan/ atau keberatan dengan putusan BPSK, maka peserta BPJS Ketenagakerjaan dapat mengajukan upaya hukum gugatan perdata kepada Pengadilan Negeri setempat. Gugatan perdata dapat diajukan atas dasar wanprestasi maupun perbuatan melawan hukum (onrechmatigedaad). Terhadap peserta BPJS Ketenagakerjaan yang tidak mampu untuk membayar biaya perkara, maka peserta dapat mengajukan gugatan secara pro deo. Ketentuan mengenai pengajuan gugatan keperdataan di Pengadilan Negeri selanjutnya diatur dalam ketentuan peraturan perundang-undangan dan HIR. 


\section{Kesimpulan}

Manfaat BPJS Ketenagakerjaan sangat banyak terutama pada saat tenaga kerja tersebut sudah dalam masa pensiun; karena mendapat uang pesangon sejumlah gaji yang disisihkan tiap bulannya pada saat aktif bekerja. Manfaat lainnya dalam hal kecelakaan kerja yang dialami oleh tenaga kerja yang telah terdaftar sebagai peserta BPJS Ketenagakerjaan dapat di cover oleh BPJS Ketenagakerjaan sesuai dengan tingkatan kebutuhan perawatannya. Pada kota Kediri, banyak perusahaan di bidang usaha kecil dan mikro yang berkembang pesat dan mampu menampung banyak tenaga kerja. Namun sebagaimana yang telah diketahui, tidak semua tenaga kerja mendapatkan fasilitas BPJS Ketenagakerjaan oleh si pemberi kerja. Sehingga perlindungan hukum bagi tenaga kerja pun tidak maksimal. Melalui pengabdian masyarakat ini, dapat diketahui bahwa untuk perusahaan yang sudah mapan, sebagian besar tenaga kerjanya telah diikutsertakan ke BPJS Keenagakerjaan. Namun terkait pemahaman dan manfaat dari BPJS Ketenagakerjaan dapat dikatakan tenaga kerja tersebut tidak terlalu mengerti. Sehingga dengan adanya pegabdian masyarakat ini mampu memberikan pemahaman yang cukup bagi tenaga kerja dan si pemberi kerja. Untuk perusahaan yang belum terlalu "mapan", dapat diketahui bahwa si pemberi kerja belum mendaftarkan tenaga kerjanya ke BPJS Ketenagakerjaan, namun perlindungan hukum yang didapat oleh tenaga kerja ini adalah dengan menerima pesangon atau tunjangan yang telah ditetapkan sebelumnya oleh si pemberi kerja.

Perlu adanya sosialisasi yang dilakukan secara periodik, terutama bagi seluuruh tenaga kerja yang masuk dalam kualifikasi peserta BPJS Ketenagakerjaan. Hal ini dilakukan untuk meningkatkan pemahaman bagi para stake holder yang terkait. Selain itu, hendaknya pihak BPJS Ketenagakerjaan membuka penyuluhan berbentuk stand yang dapat menfasilitasi tenaga kerja maupun si pemberi kerja dalam kaitannya dengan BPJS Ketenagakerjaan. Sehingga tidak ada alasan lagi untuk para pemberi kerja untuk tidak mendaftarkan tenaga kerjanya. Selain itu perlu adanya pemberian sanksi kepada si pemberi kerja apabila tidak mendaftarkan tenaga kerjanya ke BPJS Ketenagakerjaan. Sanksi ini bisa dibuat melalui peraturan tersendiri, dan harus dilaksanakan dengan pengawasan yang tepat. 


\section{Daftar Bacaan}

\section{Buku}

M. Suparman Sastrawidjaja Endang, Hukum Asuransi, Perlindungan Tertanggung, Suransi Deposito, Usaha Perasuransian (Alumni 1993).

Peter Mahmud Marzuki, Penelitian Hukum (Kencana 2005).

Saichu A, 'UMKM Berkembang Pesat, Wali Kota Kediri Raih Penghargaan Sebagai Bapak Enterpreneur' (koranmemo.com, 2019).

Sudikno Mertokusumo, Mengenal Hukum (Liberty 1989).

Zahry Vandawati Chumaida, Prinsip Itikad Baik Dan Perlindungan Tertanggung Pada Perjanjian Asuransi Jiwa, (2013) Disertasi, Fakultas Hukum Universitas Airlangga Surabaya.

Zahry Vandawati, Hilda Yunita, Buku Ajar Hukum Asuransi (2015) Fakultas Hukum Universitas Airlangga Surabaya.

\section{Jurnal}

Sari HR, 'Perlindungan Hukum Tenaga Kerja Oleh Badan Penyelenggara Jaminan Sosial Ketenagakerjaan Berdasarkan Undang-Undang No. 24 Tahun 2011' [2018] Jurnal Ilmiah Fakultas Hukum Universitas Lampung Bandar Lampung.

\section{Laman}

UMKM Berkembang Pesat, Wali Kota Kediri Raih Penghargaan sebagai Bapak Enterpreneur, http://koranmemo.com/umkm-berkembang-pesat-wali-kotakediri/.

\section{Perundang-undangan}

Undang-Undang No. 40 Tahun 2004 Tentang Sistem Jaminan Sosial Nasional.

Undang-Undang No 24 Tahun 2011 Tentang Badan Penyelenggara Jaminan Sosial.

Peraturan Pemerintah No. 44 Tahun 2011 Tentang Penyelenggaraan Program Jaminan Kecelakaan Kerja dan Jaminan Kematian.

Peraturan Pemerintah No. 45 Tahun 2015 Tentang Penyelenggaraan Program Jaminan Pensiun. 
Peraturan Pemerintah No. 46 Tahun 2015 Tentang Penyelenggaraan Program Jaminan Hari Tua.

Peraturan BPJS Ketenagakerjaan No. 01 Tahun 2016 Tentang Tata Cara Pendaftaran Bagi Pemberi Kerja dan Pekerja Penerima Upah Program Jaminan Sosial Ketenagakerjaan Pada Kanal Pelayanan BPJS Ketenagakerjaan.

HOW TO CITE: Hilda Yunita Sabrie, Rizky Amalia, Erni Agustin dan Ananda Amalia Tasya, 'Pendampingan bagi Para Tenaga Kerja sebagai Peserta BPJS Ketenagakerjaan di Kediri' (2019) Vol. 2 No. 3 Media Iuris. 